\title{
Lifelong Learning Policies: The Case of Work-Based Learning
}

\author{
Aggelos Kavasakalis (Corresponding Author) \\ University of Patras and Hellenic Open University, Dimokritou, Ilioupoli, Athens, Greece \\ Tel: 30-697-402-5628. E-mail: a.kavasakalis@gmail.com; agkav@upatras.gr
}

Foteini Liossi

Med, Higher Education Policy, University of Patras, Koimiseos Theotokou, Gastouni, Greece E-mail: fenia_lio@hotmail.com

Received: May 19, 2019

doi:10.5296/jet.v6i2.14804
Accepted: July 11, 2019 Published: July 16, 2019

URL: http://dx.doi.org/10.5296/jet.v6i2.14804

\begin{abstract}
In this paper the role of validation and recognition of non-formal and informal learning, focusing on work-based learning (WBL) is examined. The paper is based on the analysis of EU and international organizations policy documents related to developments in the areas of Lifelong Learning and the development of learning processes through WBL. In the first section, a general overview of the wider condition of the society and economy and the necessity of the discussion on the paper's theme take place. In the next part of the paper a mention of key points of the European policies on life-long learning with the focus of recognition and validation of non-formal and informal learning is been presented. In the third part, the section before the concluding remarks, the theme of Work-based learning, the development of necessary validation processes and the challenges are being analyzed.
\end{abstract}

Keywords: Work-Based Learning, Lifelong Learning, Non-Formal Learning, Informal Learning, Validation, Recognition

\section{Wider Developments in the Last Decades and Lifelong Learning Policies}

In this paper we focus on the analysis of lifelong learning policies related to the recognition of work-based learning in the context of the so-called "knowledge society". Lifelong learning policies reflect changes in technology, information, production and employment structures that have evolved since the last quarter of the 20th century and lead (according to many) to a new "revolution" perhaps of equal importance to that of the industrial revolution: the so called the knowledge society.

In this new era, developments are reversing the model of permanent tenant full-time work in a 


\section{Macrothink Mnstitute"'}

direction of work flexibility and mobility of enterprises in all widths and lengths of the world. Thus, the knowledge society "requires" an independent, highly skilled and well-networked worker. In addition, the internationalization of economy and production, the globalization, creates conditions of free movement of capital, goods and services to an unprecedented degree. With parallel developments in science, technology and culture, a new model of knowledge and know-how production, linking specialization, research, creativity and innovation with industry and markets (Kavasakalis, 2018, p. 357). In this context, lifelong learning policies seem to be an important field of the complex mosaic.

In this complex age, Europe faces challenges in the economic and social spheres. The severe economic and refugee crisis, high unemployment rates, especially youth unemployment, increased poverty and violence coupled with the lack of specialized skills of the workforce, difficulty in adapting to new technologies and global economic competition (European Council and European Commission, 2015) demonstrate the need to transform the education and training system (European Commission, 2012). Learning outcomes that someone could acquire only through formal type of learning cannot be a response to the above challenges (CEDEFOP, 2008).

Europe's need for a skilled workforce, easily adaptable to the volatile labor market needs in a spirit of innovation and entrepreneurship, as well as the need to strengthen the social inclusion of disadvantaged and low-skilled people, extends to the learning outcomes acquired through other forms of learning. Therefore, in addition to the formal education system, workplace and homework, free time, volunteering, and experiences from everyday life could provide a source of important knowledge, skills and competences (CEDEFOP, 2015). Indeed, the learning outcomes achieved in non-formal and informal learning environments are equally important for the professional and social development of the individual (Duvekot et al., 2007) and professional skills are just as necessary as the academic ones (Bruges Communiqué, 2010). In this context, lifelong learning could serve as a response to the demand for transformation of the European education and training systems and, by extension, a possible response to issues related to the economy and social cohesion in the European societies.

Initial education is no longer sufficient for the social and economic participation of individuals in the knowledge society (Duvekot et al., 2007). The continuous, lifelong investment in knowledge and skills, no matter where (formal, non-formal, informal learning) and how (e.g. using new technologies, open and distance learning processes) contributes to the promotion of the whole (personal, social, professional) integration of the individual. Therefore, it promotes the social and economic development of Europe (Commission of the European Communities, 2001). The cornerstone of Europe's success is the quality of its human resources (European Commission, 2010). In today's knowledge society, only those with the right skills will be productive, competitive and employable, resulting in a better quality of life and participation in economic, political and social life (European Commission, 2016).

\section{European Policies of Lifelong Learning and the Question of Recognition and Validation}

The effective promotion of lifelong learning will become a reality only when all forms of 


\section{Macrothink}

Journal of Education and Training

ISSN 2330-9709

2019, Vol.6, No.2

learning are validated and recognized, enabling citizens to demonstrate at any time their knowledge skills and competences, whether they are acquired in a formal, non-formal or informal learning environment. In this context, validation and recognition of alternative learning paths can be important incentives to increase participation in lifelong learning programs (European Commission, 2016) and to help the social and economic development of the individual as well as of Europe. Many European countries consider the validation of nonformal and informal learning to be an important means of promoting lifelong learning while stressing the importance of making visible and certifying the learning outcomes acquired outside the formal education system through training programs, online learning, volunteering, etc. (CEDEFOP, 2009).

More specifically, validating non-formal and informal learning is a voluntary process by an institution confirming that a person has achieved learning outcomes based on a relevant standard. The validation process identifies records, evaluates and certifies the learning outcomes achieved by a person in non-formal and informal learning environments. The validation process therefore focuses on the individual himself and the real potential of his(her) potential and leads to the acquisition of a formal professional qualification that can be used in the individual's professional career and/or continuing his(her) education and training (CEDEFOP, 2015). Thus, learning outside of the formal education system becomes visible in society, the education system and employers (CEDEFOP, 2017), giving the individual the possibility of personal and professional development. Validation is therefore the basis for recognizing non-formal and informal learning (CEDEFOP, 2008).

In this context, validation offers the possibility for the individual, through his(her) professional qualification, to apply for access to the formal education system, mainly in higher education, and in the labor market. Recognition by education and the labor market actors is that which gives the individual the ability to admit to the formal education system, e.g. in a higher education institution as well as in the labor market. Therefore, validation is a process of transforming learning outcomes acquired in non-formal and informal learning environments into a professional qualification, while recognition is a process whereby this professional qualification is taken into account by employers and educators (Martens, 2012).

Recognition of non-formal and informal learning, due to its link to the labor market and formal education, is an important factor in promoting lifelong learning and linking formal learning with alternative learning paths and the labor market. It also enhances the competitiveness and employability of the workforce, assists the development of the individual and promotes social inclusion as well as social cohesion in general. At the same time, recognition is a means of modernizing the formal education and training system, towards a more flexible system that could provide people with alternative entry paths. This enhances people's motivation to engage in lifelong learning processes and improves their self-esteem (UNESCO, 2015). It therefore appears that validation, recognition and lifelong learning are three parallel policies, where the former is a means of achieving the other two.

By recognizing the various benefits of lifelong learning, the European Union has been instrumental in developing policies to promote the validation and recognition of non-formal and informal learning since 2000. An important turning point for the promotion of lifelong 


\section{Macrothink Mnstitute"'}

learning was the Recommendation of 20th December 2012 on the validation of non-formal and informal learning. The Recommendation states that an adoption, until 2018, of national mechanisms for the validation of non-formal and informal learning should be established. In this way, individuals could utilize their learning outcomes for the continuation of their education in the formal education system and the job finding (Council of the European Union, 2012). However, before the Recommendation, a development of European education policies and formal papers were evolved to promote and validate non-formal and informal learning. The key points of this development are summarized in the next Table.

Table 1. European policies promoting validation and recognition of non-formal and informal learning

\begin{tabular}{|c|c|}
\hline Poli & ints \\
\hline $\begin{array}{l}\text { Conclusions of the Lisbon European Council } \\
\text { in March } 2000 \text { and the Stockholm European } \\
\text { Council in March } 2001 .\end{array}$ & $\begin{array}{l}\text { The adaptation of education and training to offer tailored learning opportunities to } \\
\text { individual citizens at all stages of their lives, the promotion of employability and social } \\
\text { inclusion through investment in citizens' knowledge and competences were proposed. }\end{array}$ \\
\hline $\begin{array}{l}\text { Conclusions of the Feira European Council in } \\
\text { June } 2000 .\end{array}$ & $\begin{array}{l}\text { The Member States were asked to identify coherent strategies and practical measures with } \\
\text { a view to fostering lifelong learning for all. }\end{array}$ \\
\hline $\begin{array}{l}\text { The Council Resolution of } 19 \text { December } 2002 \\
\text { and the Copenhagen Declaration of } 30 \\
\text { November } 2002 \text {. }\end{array}$ & $\begin{array}{l}\text { The development of a set of common principles regarding the validation of non-formal } \\
\text { and informal learning was requested. }\end{array}$ \\
\hline $\begin{array}{l}\text { Conclusions of the Council and of the } \\
\text { Representatives of the Governments of the } \\
\text { Member States of } 18 \text { May } 2004 \text {. }\end{array}$ & $\begin{array}{l}\text { Common European Principles for the identification and validation of non-formal and } \\
\text { informal learning were promoted. }\end{array}$ \\
\hline $\begin{array}{l}\text { The Resolution of the Council and of the } \\
\text { Representatives of the Governments of the } \\
\text { Member States of } 18 \text { May } 2006 \text {. }\end{array}$ & $\begin{array}{l}\text { The value of non-formal and informal learning within the European youth field was } \\
\text { recognized and the Member States were invited to enable the identification of } \\
\text { competences acquired through non-formal and informal learning, with a view to their } \\
\text { recognition on the labor market. }\end{array}$ \\
\hline $\begin{array}{l}\text { The Recommendation of the European } \\
\text { Parliament and of the Council of } 23 \text { April } \\
2009 \text {. }\end{array}$ & $\begin{array}{l}\text { Member States were invited to relate their national qualifications systems to the European } \\
\text { Qualifications Framework and to promote the validation of non-formal and informal } \\
\text { learning. }\end{array}$ \\
\hline $\begin{array}{l}\text { The Resolution of the Council of } 27 \\
\text { November } 2009 \text {. }\end{array}$ & $\begin{array}{l}\text { The need for full use of the range of tools established at EU level for the validation of } \\
\text { knowledge, skills and competences for the recognition of qualifications was stressed. }\end{array}$ \\
\hline $\begin{array}{l}\text { The initiatives: "Youth on the Move" and the } \\
\text { "Agenda for new skills". }\end{array}$ & $\begin{array}{l}\text { The need for more flexible learning pathways that can improve entry into and progression } \\
\text { in the labor market, facilitate transitions between the phases of work and learning and } \\
\text { promote the validation of non-formal and informal learning was emphasized. }\end{array}$ \\
\hline The Bruges Communiqué of December 2010. & $\begin{array}{l}\text { p national procedures for } \\
\text { ng. }\end{array}$ \\
\hline $\begin{array}{l}\text { The Council conclusions of } 28 \text { November } \\
2011 .\end{array}$ & $\begin{array}{l}\text { Member States were called to develop clear routes into higher education from vocational } \\
\text { and other types of education, as well as mechanisms for recognizing prior learning and } \\
\text { experience gained outside formal education and training. }\end{array}$ \\
\hline $\begin{array}{l}\text { The Resolution of the Council of } 28 \\
\text { November } 2011 \text {. }\end{array}$ & $\begin{array}{l}\text { The putting in place of fully functional systems for validating non-formal and informal } \\
\text { learning and promoting the use by adults of all ages and at all qualification levels, as well } \\
\text { as by enterprises and other organizations was defined as one of priority areas. }\end{array}$ \\
\hline
\end{tabular}

In addition, at the European Higher Education Area (EHEA), relevant policies axes have been developed since 2003 with the Berlin Communique until the latest Paris Communiqué in 2018. 


\section{Macrothink}

The Ministers of Education encourage Higher Education Institutions to recognize the learning outcomes arising in non-formal and informal learning environments in a transparent and flexible manner (Berlin Communique, 2003). In this way, higher education institutions should become more flexible and open to citizens, with multiple entry routes, respecting their unique learning experiences and abilities. It also should offer the possibility for citizens to access and graduate from higher education at any stage of their life (Paris Communique, 2018).

\section{Work-Based Learning: An Alternative Learning Path}

In the context of lifelong learning and alternative learning and training paths, a flexible route could be the work-based learning (WBL). It is about learning that results from real work irrespective of whether the work is remunerated or not (Sweet, 2013). It should not be confused with the learning that results from the programs and/or workshops of in-service training offered mainly by large companies to their employees who leave their work to attend them (ETF, 2014). The WBL can take three forms:

Informal, when learning occurs randomly at the workplace by performing the daily tasks of the worker.

Non-formal, when learning is linked to continuing vocational education and training and is conscious and structured (CEDEFOP, 2015).

And, finally, formal when linked to initial vocational education and training and part of upper secondary and/or tertiary education (e.g., professional colleges, "sandwich-courses") aiming at equipping young learners with skills in line with the needs of the labor market (European Commission, 2010) in order to achieve a smooth transition from workplace education.

In this paper, the WBL is analyzed as a part of continuing vocational education and training (CVET) as it constitutes an alternative path to non-formal learning in this context. WBL in initial vocational education and training (IVET), since it usually takes place in formal education environments, involves formal learning, leading to the acquisition of a nationally recognized qualification (European Commission, 2013). Therefore, usually WBL in IVET is not an alternative learning and training path. For this reason, in this paper we will not focus on this type of WBL. The WBL in CVET is defined as intended and structured (Note 1) learning of direct relevance to a worker's current or future tasks and taking place in simulated or real work conditions, or outside of the workplace (Note 2) but with specific learning tasks that must be applied in the workplace and afterwards reflected upon (train-apply-reflect method). Workbased learning in CVET aims to improve workers' mastery of work tasks through providing them with the necessary skills, for example basic, soft or transversal (CEDEFOP, 2015, p. 15).

\subsection{Work-Based Learning in Continuing Vocational Education and Training: Developments}

Policies are being developed in Europe to promote recognition of WBL in the CVET as its contribution is crucial to addressing the societal and economic challenges that Europe is experiencing (CEDEFOP, 2015). In particular, in the Bruges Communiqué (at 7 December 2010), the Ministers for Vocational Education and Training, the European Social Agencies and 


\section{MInstitute Macrothink $^{m}$}

the European Commission, recognized that in the knowledge society, professional skills and competences are as important as the academic ones. Therefore, WBL in CVET has many benefits at individual, social and economic level and it is for counties' benefit to adapt their national legislation to validate the non-formal learning resulting from the WBL in CVET until 2020 (Bruges Communiqué, 2010). In addition, Riga's conclusions adopted on 22 June 2015 emphasize the importance of promoting WBL and the need of improving the recognition system it up to 2020, in order to develop qualitative and related to the labor market competences and learning outcomes (Riga Conclusions, 2015). This could increase the interest in participating in this form of learning and will help to make its implementation a reality within the framework of the CVET.

WBL in CVET through the provision of skills and competences relevant to the labor market is considered to be able to cope with:

$>$ The mismatch between the labor and labor skills required (Note 3) (European Commission, 2013) and

$>$ The high unemployment rates, as this enhances the employability of the individual.

It is also argued that it could cope with the aging of Europe's population and the resulting prolongation of people's working lives by providing them with alternative and flexible lifelong learning pathways to harmonize their skills based on the ever-changing labor market needs in order to maintain their job (Bruges Communiqué, 2010). Thus, through WBL in CVET productivity and innovation in the enterprise, Europe's economic competitiveness and social inclusion are enhanced. Citizens could develop their professional identity, strengthen their selfesteem (Bruges Communiqué 2010) and have the opportunity to participate in social, political and economic life. At the same time, it is considered that the "Europe 2020" target of achieving the employment rate of $75 \%$ by 2020 and the "Education and Training 2020" program target, the participation rate of adults in training programs should be reached to $15 \%$ by 2020 could become a reality (CEDEFOP, 2014). In the following table the significant benefits from WBL to all stakeholders: society and the economy, enterprises, individuals, are summarized. Consequently, learning through work experience in CVET seems to have significant benefits for all stakeholders: society and the economy, enterprises, individuals, as summarized below in Table 2.

Table 2. Benefits though WBL in CVET

\begin{tabular}{lll}
\hline Society and economy & Enterprises & Individuals \\
\hline Economic growth & Innovative ability & Career development \\
Competitiveness and innovation & Employees' productivity & Employment \\
Social cohesion and inclusion & Employees' satisfaction & Personal development \\
Equality & Inclusion of disadvantaged & Earnings \\
Civic engagement & Firms'performance & Life satisfaction \\
\hline
\end{tabular}

Source: CEDEFOP, 2014 


\section{Macrothink}

3.2 Work-Based Learning in Continuing Vocational Education and Training: Recognition Processes and Challenges

The recognition of WBL in CVET no matter how important it is, faces challenges in its implementation, as there is still a lack of systematic knowledge in the field, with the result that policy makers find it difficult to make informed decisions both at a theoretical level and at the policy level to promote recognition (CEDEFOP, 2015). In particular, the WBL in CVET as takes place outside formal education and training system does not lead to the acquisition of a recognized qualification. Often, participants simply receive a program completion certificate. This core weakness discourages citizens from attending such programs. Indeed, the absence of an institutionalized system of validation of the learning outcomes achieved through WBL in CVET makes it impossible to become visible by the stakeholders and to check the effectiveness of these programs (CEDEFOP, 2015).

It also meets challenges during the process of evaluation of learning outcomes, which is very important, as this process confirms their possession and, by extension, the quality of WBL programs in CVET. In this way, a culture of trust is cultivated among stakeholders, with the result that the certified qualification could be recognized and used for mobility purposes or for professional and/or academic purposes. Sometimes the evaluation of learning outcomes is easily and fairly done outside the workplace, while some learning outcomes are difficult and costly to evaluate outside the work environment. Thus, the authenticity of the assessment may need to be balanced with the choice of the most cost-effective evaluation tools (ETF, 2014). In addition, there are challenges concerning of whom is responsible for evaluating and certifying learning outcomes. Therefore, organizations that are qualified to evaluate learning outcomes due to a lack of good cooperation between stakeholders may be reluctant to participate in the process, something that will have a negative impact on the quality of the evaluation (ETF, 2014).

In any case, these challenges weaken WBL's attractiveness to CVET. As a result, citizens do not have a strong incentive to participate such programs and have limited interest in choosing alternative learning pathways and engaging in lifelong learning programs. Essentially, improving recognition procedures may be the most powerful means of promoting the implementation of WBL in the CVET. There is a need for political will and strong cooperation of all stakeholders at both national and European level to remove obstacles to recognition and to enable WBL in the CVET to be effectively implemented.

\section{Concluding Thoughts}

The challenges facing Europe today (at economic, cultural and societal level), the so-called "knowledge society" and the change in the productive model that this implies, increase the need for people to engage in lifelong learning programs, as well as the creation of alternative learning and training pathways. The formation of flexible learning and training paths should be accompanied by the validation and recognition of the learning outcomes achieved through them, in order to give people a strong incentive to pursue flexible learning paths, but also to make full use of their potential (CEDEFOP, 2015). However, despite the benefits, validating and recognizing alternative learning paths learning outcomes meets a number of challenges. The EU countries should deal with this major weakness. 


\section{MInstitute Machk $_{\text {Int }}^{\text {Mach }}$}

WBL in CVET seems to be an effective and flexible form of learning for adults as the workplace is an important source of learning and training for employees and a means of improving the productivity and innovation of the enterprise. In this context, it is necessary to regulate a system of validation of the learning outcomes achieved in order to recognize the acquired professional qualifications and enable citizens to make full use of the opportunities offered by the recognition of these qualifications (CEDEFOP, 2015). It is for the benefit of people, societies and countries if WBL in CVET receives more attention, action and stronger cooperation among stakeholders in order to develop the appropriate policies that will implement its validation and recognition in practice so that its potential in Europe could be exploited in the future (CEDEFOP, 2015).

Recognition of alternative learning and training pathways, in particular WBL in CVET is a flexible and inclusive policy in relation to recognizing only the learning outcomes of formal education and training. The ability given to the person to make visible the learning outcomes he(she) has achieved independently of the learning path that has pursued to achieve them, offers important opportunities for a personal, professional and academic development. At the same time, economic growth, which in modern social conditions relies heavily on knowledge, as well as social inclusion, is reinforced. Recognizing all the learning experiences offered through day-to-day activities, such as learning at work, and indeed the opportunities offered by their recognition, seem to be an interesting development in relation to the recognition of only formal qualifications and the "monopoly" of formal education in providing opportunities for the development of professional and academic careers.

\section{Notes}

Note 1. WBL in CVET is a structured learning with regard to learning outcomes, the teaching plan, the place and time of learning (CEDEFOP, 2015).

Note 2. In example in a vocational education and training institute.

Note 3. Although 5.6 million people in Europe are unemployed, 36\% of employers find it hard to find employees with the skills they want.

\section{References}

Bologna Process. (2003). Realizing the European Higher Education Area, Communiqué of the Conference of Ministers responsible for Higher Education, Berlin. Retrieved from http://media.ehea.info/file/2003_Berlin/28/4/2003_Berlin_Communique_English_57728 4.pdf

Bologna Process. (2018). Communiqué of the meeting of European Ministers in charge of Higher Education, Paris. Retrieved from http://www.ehea.info/media.ehea.info/file/2018_Paris/77/1/EHEAParis2018_Communiq ue_final_952771.pdf

CEDEFOP, European Commission, ICF. (2017). European inventory on validation of nonformal and informal learning. Synthesis report. Luxembourg: Publications Office. Retrieved from http://www.cedefop.europa.eu/en/events-and-projects/projects/validation - 
non-formal-and-informal-learning/european-inventory

CEDEFOP. (2008). Validation of informal and non-formal learning in Europe, A snapshot 2007. Luxembourg: Office for Official Publications of the European Communities. Retrieved from http://www.cedefop.europa.eu/en/publications-and-resources/ publications/4073

CEDEFOP. (2009). European guidelines for validating non-formal and informal learning. Luxembourg: Office for Official Publications of the European Communities. Retrieved from http://www.cedefop.europa.eu/node/11010

CEDEFOP. (2014). Work-based learning (WBL) trends in continuous vocational education and training (CVET) (pp. 10-11). ETF event 'Work-based learning in VET matters', Turin. Retrieved from http://www.ipq.org.ua/upload/files/files/3_Dehmel.pdf

CEDEFOP. (2015). European guidelines for validating non-formal and informal learning. Luxembourg: Office for Official Publications of the European Communities. Retrieved from http://www.cedefop.europa.eu/en/publications-and-resources/publications/4054

CEDEFOP. (2015). Work-based learning in continuing vocational education and training: policies and practices in Europe. Luxembourg: Publications Office of the European Union. Retrieved from http://www.cedefop.europa.eu/en/publications-andresources/publications/5549

Commission of the European Communities. (2001). Making a European Area of Lifelong Learning a Reality, COM (2001) 678 final. Retrieved from http://www.europarl.europa.eu/meetdocs/committees/cult/20020122/com(2001)678_en.p df

Council of the European Union, European Commission. (2010). The Bruges communiqué. Retrieved from https://cumulus.cedefop.europa.eu/files/vetelib/2010/75928.pdf

Council of the European Union, European Commission. (2015). Joint Report of the Council and the Commission on the implementation of the strategic framework for European cooperation in education and training (ET 2020). New priorities for European cooperation in education and training. Official Journal of the European Union, C417. Retrieved from https://eur-lex.europa.eu/legalcontent/EN/TXT/PDF/?uri=CELEX:

$52015 \mathrm{XG} 1215(02) \&$ from $=\mathrm{EL}$

Council of the European Union. (2012). Council Recommendation of 20 December 2012 on the validation of non formal and informal learning. Official Journal of the European Union, C398. Retrieved from http://www.cedefop.europa.eu/files/Council_ Recommendation_on_the_validation_20_December_2012.pdf

Duvekot, R., Scanlon, G., Charraud, A. M., Schuur, K., ..., \& Clarus, R. (2007). Managing European diversity in lifelong learning. The many perspectives of the valuation of prior learning in the European workplace. Vught, Amsterdam: Foundation EC-VPL \& HAN. Retrieved from http://www.ec-vpl.eu/managing-european-diversity-in-lifelong-learning/

ELGPN [European Lifelong Guidance Policy Network]. (2014). Lifelong Guidance Policy 
Development: Glossary. $\quad$ Finland: Saarijarvi. Retrieved from http://www.elgpn.eu/publications/browse-by-language/english/elgpn-tools-no.-2llgglossary/

ETF (European Training Foundation). (2014). Work-based Learning: A handbook for Policy Makers and Social Partners in ETF Partner Countries, ETF. Retrieved from http://www.etf.europa.eu/webatt.nsf/0/8EFD210012D6B04EC1257CE60042AB7E/\$file/ Work-based\%20learning_Handbook.pdf

European Commission. (2010). Communication from the Commission to the European Parliament, the Council, the European Economic and Social Committee and the Committee of the Regions. A new impetus for European cooperation in Vocational Education and Training to support the Europe 2020 strategy, COM final. Retrieved from https:/eur-lex.europa.eu/LexUriServ/LexUriServ.do?uri=COM:2010:0296:FIN:EN:PDF

European Commission. (2012). Press Release: Commission presents new Rethinking Education strategy. Brussels/Strasbourg. Retrieved from http://europa.eu/rapid/pressrelease_IP-12-1233_en.htm

European Commission. (2013). Work-Based Learning in Europe: Practices and Policy Pointers. Retrieved from http://ec.europa.eu/dgs/education_culture/repository/education/ policy/vocational-policy/doc/alliance/work-based-learning-in europe_en.pdf

European Commission. (2016). Education and Training Monitor 2016. Directorate-General for Education and Culture. Retrieved from https://ec.europa.eu/education/sites/ education/files/monitor2016_en.pdf

Kavasakalis, A. (2018). Training and lifelong learning policies. In Th. Sakellaropoulos, Xr. Oikonomou, Xr. Skamnakis, \& M. Aggelaki (Eds), Social Policy. Athens: Dionikos, ISBN: 9789606619830.

Latvian Presidency of the Council of the European Union and European Commission. (2015). Riga conclusions 2015. On a new set of medium-term deliverables in the field of VET for the period 2015-20, as a result of the review of short-term deliverables defined in the 2010 Bruges Communiqué. Retrieved from http://ec.europa.eu/dgs/education_culture/ repository/education/policy/vocational-policy/doc/2015-riga-conclusions_en.pdf

Martens, J. (2012). Recognition of Non-formal and Informal Competences of Workers' Representatives. Düsseldorf. Retrieved from http://www.solidar.org/system/downloads/ attachments/000/000/225/original/kompetenzf_finalpublication.pdf?1457601291

Sweet, R. (2013). Work-based learning: Why? How? In Revisiting Global Trends in TVET: Reflections on Theory and Practice, UNESCO-UNEVOC, Bonn. Retrieved from http://www.unevoc.unesco.org/fileadmin/up/2013_epub_revisiting_global_trends_in_tvet _chapter5.pdf

UNESCO Institute for Lifelong Learning. (2015). Recognition, Validation and Accreditation of Non-formal and Informal Learning in UNESCO Member States. Hamburg: UIL. Retrieved from http://unesdoc.unesco.org/images/0023/002326/232656e.pdf 


\section{Macrothink

Copyright Disclaimer

2019, Vol.6, No.2

Copyright reserved by the author(s).

This article is an open-access article distributed under the terms and conditions of the Creative Commons Attribution license (http://creativecommons.org/licenses/by/3.0/). 